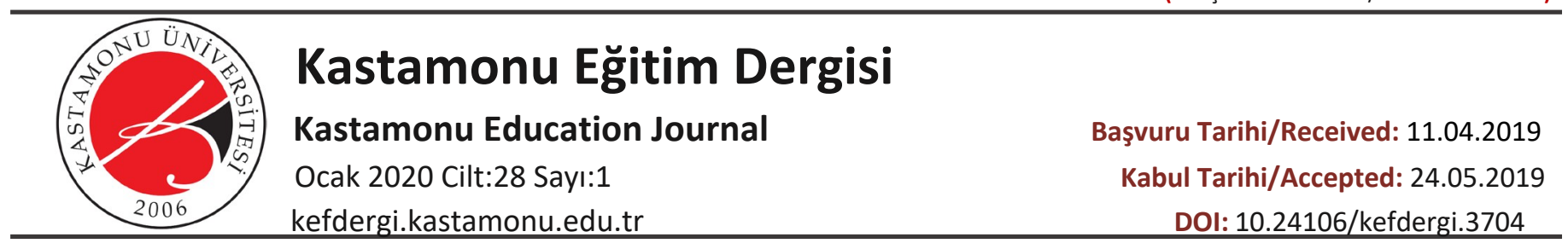

\title{
Okul Öncesinde Fen Eğitimine Yönelik Öz Yeterlik Ölçeğinin Geliştirilmesi1,2
}

\section{Development Self Efficacy Scale for Science Education in Pre-School Education}

\section{Öz}

\author{
Aycan BULDUR ${ }^{3}$ \& Fatma ALISINANOĞLU4
}

Bu araştırmada okul öncesi öğretmen adaylarının fen eğitimine yönelik öz yeterliklerini belirlemekte kullanılması amacıyla "Okul Öncesinde Fen Eğitimine Yönelik Öz Yeterlik Ölçeği" (OFEYÖÖ) geliştirilmiştir. Ölçek geliştirme çalışmasının çalışma grubunu iki farklı devlet üniversitesinin Okul Öncesi Öğretmenliği Anabilim dalında öğrenim gören 362 öğretmen adayı oluşturmuştur. Ölçek geliştirme çalışmasının ilk aşamasında doküman incelemesi yoluyla alan yazın incelemesi yapılmıştır. Daha sonra oluşturulan madde havuzu uzman görüşlerine sunulmuştur. Uzman görüşlerinden sonra elde edilen taslak form çalışma grubunda yer alan öğretmen adaylarına uygulanmıştır. Ölçeğin yapı geçerliliğini belirlemek amacıyla açımlayıcı ve doğrulayıı faktör analizi kullanılmıştır. Beşli dereceleme sistemine göre geliştirilen ölçekte 16 madde yer almaktadır.

Anahtar Kelimeler: okul öncesi eğitimi, öğretmen adayı, fen eğitimi, öz- yeterlik

\section{Abstract}

In this study, "Self Efficacy Scale for Science Education in Pre-School Education" was developed in order to use pre-school teacher candidates to determine their self-efficacy towards science education. The study group of the study consisted of 362 prospective pre-school teachers from two different state universities. In the first phase of the scale development study, a literature review was conducted through document review. Subsequently, the pool of substances was submitted to expert opinions. The draft form obtained after the expert opinions was applied to the prospective teachers in the study group. Exploratory factor analysis and confirmatory factor analysis were performed in order to examine the construct validity of the scale. There are 16 items on the scale developed according to the five grading system.

Keywords: pre-school education, prospective teacher, science education, self-efficacy

\footnotetext{
${ }^{1}$ Bu çalışma ilk yazarın, ikinci yazar danışmanlığında hazırladığı yüksek lisans tezinden üretilmiştir.

${ }^{2}$ Bu çalışma, Sivas Cumhuriyet Üniversitesi Bilimsel Araştırma Projeleri (CÜBAP) tarafından EGT 031 proje numarası ile desteklenmiştir.

${ }^{3}$ Cumhuriyet Üniversitesi, Türkiye

${ }^{4}$ Biruni Üniversitesi, Türkiye
} 


\section{Extended Abstract}

Introduction: The effectiveness of science education in pre-school period is directly related to teachers. Teachers' performances are known to depend on their beliefs. (Nespor, 1987). In particular, it is known that teachers' self-efficacy beliefs affect the practices they perform in the classroom and teachers with high self-efficacy are more willing to teach. In addition, the results obtained from the researches about self-efficacy beliefs in the education process of teachers will provide important data about the points to be considered in the education process in order to increase the success in the courses where the student achievement is very low (Üredi and Üredi, 2006). Based on this, self-efficacy perceptions of teacher candidates are an important factor in providing an effective science education. Based on the importance of the concept of self-efficacy in teaching processes and the need for a measurement tool that can be used to improve the self-efficacy level of pre-school science education, a scale has been developed to determine pre-school teacher candidates' self-efficacy levels for science education.

Method: When the literature is examined, it is thought that this scale will make a significant contribution to the related literature because there is no measurement tool that can be used to measure the self-efficacy of pre-school teacher candidates for science education. The aim of this research is to; develop a scale to determine pre-school teacher candidates' self-efficacy for science education and to examine whether the developed scale meets the required validity and reliability criteria. In this study, survey model was used. The study group of the scale development study consisted of 362 pre-service teachers from two different state universities. When data from 362 teacher candidates were analyzed, the data of 56 participants were excluded from the analysis due to missing data and outliers. As a result, the analyzes were completed with data from 306 teacher candidates. A 42-item draft scale was prepared based on the data obtained from the examination of the document and the data analyzed from the composition of the teacher candidates. In order to ensure the face validity of the scale, the scale items were examined by five preschool education experts, two pre-school teachers and a measurement and evaluation specialist, and the number of items on the scale was reduced to 37 in line with the feedback received. In order to ensure the face validity, the pre-pilot implementation of the 37-item draft scale was conducted with a group interview with 10 pre-service teachers. In this interview, all items in the scale were examined. The parts which are not understood in the expressions have been identified and changed according to the suggestions. In the final stage of the drafting process, the scale was checked by a language expert and the scale was finalized. The scale was developed according to the five grading system. Exploratory factor analysis (EFA) and confirmatory factor analysis (CFA) were applied to determine the construct validity of the scale. In order to determine the structure of the factors in the EFA, rotated basic component analysis was used. The internal consistency coefficient of the scale was calculated with the Cronbach alpha value. Item-total correlations were calculated in order to determine how sufficient each item in the scale was able to differentiate individuals in terms of the characteristics they measured.

Findings: The Cronbach alpha reliability coefficient was calculated to determine the internal consistency of the items collected under the single factor. The coefficient value was calculated as .92. The item total correlations were calculated in order to determine the reliability of the dimensions determined by CFA and the reliability of each item found in the scale in terms of the characteristics they measured in distinguishing them. Then, un-related samples t-test was performed for determine the significance of the difference between item scores of the upper $27 \%$ and lower $27 \%$ groups determined according to the score obtained. The scale developed has sufficient validity and reliability conditions to measure pre-school teacher candidates' self-efficacy for science education.

Conclusion: In this study, it can be said that this scale can be easily used in the research which will examine the self-efficacy of pre-school teacher candidates. On the other hand, the data obtained by using this scale may provide data diversity in mixed method researches about pre-school teacher candidates' self-efficacy towards science education. Moreover, it is recommended that the scale can be used in the sample of preschool teachers by conducting validity reliability studies in the sample of preschool teachers together with minor corrections to be made on the items in this scale. 


\section{Giriş}

Okul öncesi eğitim çocuğun inceleme, araştırma ve gözlem yapma becerilerini geliştirmesi, bilimsel düşünme becerisini desteklemesi açısından oldukça önemlidir (Gürdal, Çağlar, Şahin, Okçun ve Macaroğlu, 1993). Bu bağlamda erken çocukluk eğitiminde etkinlik türlerinden biri olan fen eğitimi, iletişim kurma tahminde bulunma, gözlem yapma, sınıflama, çıkarım yapma, basit ölçümler yapma gibi fen bilimlerinde ve yakın çevremizde hayatımızın her anında ihtiyaç duyacağımız bilimsel süreç becerilerini öne çıkaran bir yaklaşım esas alınarak gerçekleştirilmelidir (Güler ve Bıkmaz, 2002). Okul öncesi dönemde özellikle çevrelerine karşı ilgili olan çocuklar, sürekli sorular sorarak karşılaştıkları olaylar hakkında neden sonuç ilişkisi kurmaya çabalamaktadır. Çocuklar çevreyle yoğun etkileşime girerek fiziksel dünyaya ait deneyimlerini ve bilgilerini artırıp, meraklarını gidermektedirler (Alisinanoğlu, Özbey ve Kahveci, 2011). Ailelerin çocuklarla beraber yaşadıkları doğal çevrede verimli zaman geçirmesi çocukların çevrelerine karşı ilgilerini artırmaktadır (Kesicioğlu ve Alisinanoğlu,2009).

Okul öncesi dönemde verilecek fen eğitiminin etkililiği öğretmenlere doğrudan bağlıdır. Öğretmenlerin performanslarının ise sahip oldukları inançlara bağlı olduğu bilinmektedir (Nespor, 1987). Özellikle öğretmenlerin öz yeterlik inançlarının onların sınıf içinde gerçekleştirdikleri uygulamaları etkilediğini ve öz yeterliği yüksek olan öğretmenlerin öğretim konusunda daha istekli davrandığı bilinmektedir. Öğretmenlerin zor ve motivasyonu düşük çocuklarda dahil olmak üzere, çocukların öğrenme ürünlerini etkileyebilecek kapasiteye sahip olduklarına ilişkin yargıları olarak tanımlanabilen öğretmen öz yeterlik inancı kavramı öğretim sürecinde güçlü etkilere sahiptir (Küçükyılmaz ve Duban, 2006). Bu bağlamda öğretmenlerin fen eğitimi vermek konusunda kendilerini ne kadar yeterli gördüklerinin onların performanslarını da etkileyeceği düşünülmektedir. Çünkü fen eğitimi vermek konusunda kendilerini yeterli hisseden yani öz yeterlikleri yüksek öğretmenler eğitim sürecinde daha etkili olabilecektir (Chan, 2003). Bu bilgiler ışığında, öğretmenlerin ve geleceğin öğretmenleri olacak öğretmen adaylarının fen eğitimi vermeye yönelik öz yeterlik inançlarının; çocukların motivasyonlarını ve başarılarını arttırmakta, sınıf yönetimiyle ilgili sorunları çözebilmelerinde, etkili planlama, uygulama ve değerlendirme faaliyetleri gerçekleştirmelerinde önemli bir rol oynadığı söylenebilir (Özdemir, 2008). Öz yeterlik inançlarının eğitim sürecindeki bu kritik rolü geleceğin öğretmeni olacak öğretmen adaylarının yetiştirilmesinde bu inançlara verilmesi gereken önemi de göstermektedir. Çünkü bugünün öğretmen adayları geleceğin öğretmenleri olacaklardır ve onların hizmet öncesi dönemde sahip olduğu düşüncelerin ve yaşadıkları problemlerin meslek hayatlarındaki performanslarını etkileyeceği aşikârdır. Eğitim ve öğretim ortamlarında verilecek fen eğitiminin kalitesi öğretmen adaylarının mesleğe yeterli biçimde hazırlanmasına bağlıdır (Briscoe ve Stout, 2001). Özellikle bu alanlarda yeterli motivasyon ve öz yeterlik inançları sağlanmadıkça, öğretmenlerin istenen seviyede bir öğretim sağlamaları zor görünmektedir (Tosun 2000). Buradan yola çıkarak iyi bir fen eğitiminin yapılabilmesinde de öğretmen adaylarının öz yeterliklerinin önemli bir etken olduğu söylenebilir.

Öğretmen adayların ve öğretmenlerin belirli bir alana özgü öz yeterlik inançlarına ait veriler, öğretmenlerin davranışlarının net anlaşılmasını sağlamaktadır. Bununla birlikte öğretmenlerin eğitim-öğretim sürecinde öz yeterlik inançları ile ilgili araştırmalardan varılan sonuçlar fen gibi öğrenci başarısının çok düşük olduğu derslerde başarıyı arttırmak için eğitim öğretim sürecinde dikkat edilmesi gereken noktalara ilişkin önemli veriler sağlayacaktır (Üredi ve Üredi, 2006). Bundan yola çıkarak etkili bir fen eğitiminin verilebilmesinde de öğretmen adaylarının öz yeterlik algıları önemli bir etkendir.

\section{Araştırmanın Amacı ve Önemi}

Bir işi yapmak için gerekli becerilere sahip olmaya ilişkin kişisel inanç olan öz yeterlik (Bandura, 1977) kişilerin bilgi ve davranışlarına aracılık edip onları bağdaştırarak bu değişkenlerin etkin bir şekilde birlikte işlemelerini sağlamakta merkezi bir rol oynar (Teti ve Gelfand, 1991). Bu nedenle, öz yeterlik inancı kritik bir işlem görmektedir. Çünkü farklı bir öğrenmenin meydana gelmesi ya da yeni bir becerinin kazanılmasında ve daha sonra bu yeni becerinin ya da öğrenimin uygulamaya konmasında etkilidir (Kotaman, 2008).

Bu bağlamda ilgili alan yazın incelendiğinde (Alabay, 2006; Ekinci-Vural ve Hamurcu, 2008; Kahyaoğlu ve Yangın, 2007; Olgan, Güner-Alpaslan ve Öztekin, 2014; Okur-Akçay, 2015) okul öncesi öğretmen adaylarının fen öğretime yönelik öz yeterlikleri ile ilgili bazı çalışmaların yapıldığı göze çarpmaktadır. Ancak bu araştırmalarda kullanılan veri toplama aracına genelde Enochs ve Riggs (1990)tarafından sınıf öğretmenleri örnekleminde geliştirilen ve Bıkmaz (2004) tarafından sınıf öğretmeni adayları örnekleminde Türkçeye uyarlanan "Sınıf Öğretmeni Adaylarının Fen Öğretiminde Öz-yeterlik İnancı Ölçeği” yada genel olarak "Öğretmen adayı öz-yeterlik ölçeği”'nin kullanıldığı 
görülmüştür. Ancak okul öncesi dönem fen eğitimin kendine özgü yönleri dikkate alındığında doğrudan okul öncesi dönem fen eğitimine yönelik bir öz yeterlik ölçeğine ihtiyaç duyulduğu açıktır.

Öz-yeterlik kavramının öğretim süreçlerindeki bu öneminden ve okul öncesi dönem fen eğitimine yönelik öz yeterlik düzeyini geliştirmekte kullanılabilecek bir ölçme aracına duyulan ihtiyaçtan hareketle bu araştırma kapsamında okul öncesi öğretmen adaylarının fen eğitimine yönelik öz yeterlik düzeylerini belirlemek amacıyla bir ölçek geliştirilmiştir. Illgili alan yazın incelendiğinde okul öncesi öğretmen adaylarının fen eğitime yönelik öz yeterliklerini ölçmede kullanılabilecek bir ölçme aracına rastlanmamış olması nedeniyle bu ölçeğin ilgili alan yazına önemli katkılar sağlayacağı düşünülmektedir.

Bahsedilenlerden hareketle bu araştırmanın amacı; Okul öncesi öğretmen adaylarının fen eğitimine yönelik öz yeterliklerini belirlemek amacıyla bir ölçek geliştirmek ve geliştirilen ölçeğin gerekli geçerlik ve güvenirlik ölçütlerini sağlayıp sağlamadığını incelemektir.

\section{Yöntem}

\section{Araştırmanın Modeli}

Genel tarama modeli esas alınarak yürütülen araştırmalarda geçmişte veya halihazırda var olan bir durumun müdahale edilmeden betimlenmesi esas alındığından dolayı (Karasar, 2011) Okul Öncesinde Fen Eğitimine Yönelik Öz Yeterlik Ölçeği (OFEYÖÖ)'nin' geliştirildiği bu çalışmada araştırmada genel tarama modeli esas alınmıştır.

\section{Çalışma Grubu}

Ölçek geliştirme çalışmasının çalışma grubunu iki farklı devlet üniversitesinin Okul Öncesi Öğretmenliği Anabilim dalında öğrenim gören 362 öğretmen adayı oluşturmuştur. 362 öğretmen adayından alınan veriler incelendiğinde, eksik veriler ve aykırı değerler nedeniyle 56 katılımcının verileri analiz dışı bırakılmıştır. Sonuç olarak analizler 306 öğretmen adayından elde edilen veriler ile tamamlanmıştır.

\section{Ölçek Geliştirme Süreci}

Okul öncesi öğretmen adaylarının fen eğitimine yönelik öz yeterlik ölçeğinin geliştirme aşamasında ilk olarak yurt içi ve yurt dışında yapılan araştırmalar incelenmiştir. Doküman incelemesi yoluyla alan yazın incelemesi yapılmıştır (Bıkmaz, 2004; MEB, 2012; Öncü, 2012; Yıldırım ve İlhan, 2010). Bu incelemede daha önce öğretmen adaylarına yönelik geliştirilen öz yeterlik ölçekleri, Mili Eğitim Bakanlığı (2012) tarafından yayınlanan "Okul Öncesi Öğretmeni Özel Alan Yeterlikleri" kriterleri incelenmiştir. Bu aşamadan sonra 3. sınıfta öğrenim gören ve "Okul Öncesinde Fen Eğitimi" dersini almış 20 öğretmen adayına Okul Öncesinde fen eğitimi yapmak konusunda kendilerini ne kadar yeterli hissettikleri hakkında bir kompozisyon yazdırılmıştır. Doküman incelemesinden elde edilen bilgiler ve öğretmen adaylarının kompozisyonlarından analiz edilen verilerden yola çıkılarak 42 maddelik taslak ölçek hazırlanmıştır.

Ölçeğin yüzeysel geçerliğini sağlamak için ölçek maddeleri beş okul öncesi eğitimi uzmanına, iki okul öncesi öğretmenine ve bir ölçme ve değerlendirme uzmanına incelettirilmiş ve gelen dönütler doğrultusunda ölçekteki madde sayısı 37'ye düşürülmüştür. Yine yüzeysel geçerliğin sağlanabilmesi amacıyla 37 maddelik taslak ölçeğin ön pilot uygulaması 10 öğretmen adayı ile grup görüşmesi yapılarak yürütülmüştür. Bu görüşmede ölçekteki tüm maddeler incelenmiştir. Iffadelerde anlaşılmayan kısımlar tespit edilmiş ve öneriler doğrultusunda değiştirilmiştir. Taslak form oluşturma işleminin son aşamasında ise ölçek bir dil uzmanı tarafından kontrol edilmiş ve ölçeğe son hali verilmiştir. Ölçek beşli dereceleme sistemine göre geliştirilmiş ve her madde için "Her zaman", "Genellikle", "Sık sık", "Bazen" ve "Hiçbir zaman" düzeyleri kullanıımıştır.

\section{Verilerin Analizi}

Ölçeğin kapsam ve dil geçerliliğini sağlamak amacıyla uzman görüşlerine başvurulmuştur. Ölçeğin yapı geçerliliğini belirlemek için açımlayııı faktör analizi (AFA) ve doğrulayııı faktör analizi (DFA) uygulanmıştır. AFA'da faktörlerin yapısını belirlemek amacıyla döndürülmüş (varimax) temel bileşenler analizi kullanılmıştır. Ölçeğin iç tutarlılık katsayısı ise Cronbach alpha değeriyle hesaplanmıştır. Ölçekte yer alan her bir maddenin, ölçtükleri özellik açısından ayırt ediciliklerini belirlemek amacıyla madde-toplam korelâsyonları hesaplanmıştır. Daha sonra t-testi aracılığıyla, ortalama puanlar doğrultusunda belirlenen üst \% 27 ve alt \% 27'lik grupların madde puanları arasındaki farkın anlamlılığı sınanmıştır. 


\section{Bulgular}

Bu bölümde sırasıyla ölçeğin yapı geçerliliğine, güvenilirliğine ve ölçekte yer alan maddelerin ayırt edicilik özelliğine ilişkin bulgulara yer verilmiştir.

Yapı Geçerliliğine İlişkin Bulgular

\section{Açımlayıcı Faktör Analizine (AFA) ìlişkin Bulgular}

Okul öncesinde fen eğitimine yönelik öz yeterlik ölçeğinin faktör analizi yapılmadan önce ilk olarak verilerin faktör analizine uygun olup olmadığını belirlemek amacıyla Kaiser-Meyer-Olkin katsayısına (KMO) ve Bartlett küresellik testi sonuçları incelenmiştir. KMO katsayısı 0.60 'dan yüksek ve Bartlett testinin anlamlı çıkmasının verilerin faktör analizi için uygun olduğunu gösterdiği bilinmektedir (Büyüköztürk, 2008). Araştırmada, ölçeğin KMO değeri 0.94, Bartlett küresellik testi sonucu da [2434.53 $(p<.01)]$ anlamlı olarak bulunmuştur. Bu bulgular verilerin faktör analizi için uygun olduğu göstermiştir.

Açımlayıcı faktör analizine 37 maddelik ölçekle başlanmıştır. İlk analiz sonuçlarına bakıldığında ölçeğin öz değeri 1'den büyük 9 faktörde toplandığı görülmüştür. Ancak ilk faktörün öz değerinin ikinci faktörün 6 katından fazla olması ölçeğin tek faktörlü olabileceğine işaret etmiştir. Bu faktörlerin açıkladığı toplam varyans \% 58.69 olmuştur. Veriler varimax dik döndürme tekniği kullanılarak incelendiğinde 9 maddenin aynı anda iki faktörde yüksek yük değerine sahip olduğu görülmüştür. Bu maddeler çıkarılarak binişme olmayana kadar döndürme işlemine devam edilmiştir. Döndürme işlemlerinin sonunda binişme özelliği gösteren madde olmadığı ve ölçeğin 16 maddelik tek faktörde toplandığı görülmüştür. Maddelerin faktör yük değerinin alt sınırı .30 (Büyüköztürk, 2008) olarak belirlenmiş ve bu değerden düşük yük değerine sahip maddeler ölçekten çıkarılmıştır. OFEYÖÖ’ye ilişkin AFA sonuçları Tablo 1'de gösterilmektedir.

\section{Tablo 1. OFEYöö’YE ilişkin AFA sonuçları}

\begin{tabular}{lll}
\hline Madde & $\begin{array}{l}\text { Faktör Ortak } \\
\text { Varyansı }\end{array}$ & $\begin{array}{l}\text { Faktör Yük } \\
\text { Değerleri }\end{array}$ \\
\hline Mo & 0.65 & 0.81 \\
M23 & 0.63 & 0.80 \\
M35 & 0.62 & 0.79 \\
M18 & 0.61 & 0.78 \\
M19 & 0.56 & 0.75 \\
M27 & 0.55 & 0.74 \\
M15 & 0.51 & 0.71 \\
M36 & 0.46 & 0.68 \\
M30 & 0.45 & 0.67 \\
M25 & 0.45 & 0.67 \\
M28 & 0.44 & 0.66 \\
M2 & 0.40 & 0.64 \\
M17 & 0.39 & 0.63 \\
M3 & 0.38 & 0.62 \\
M20 & 0.28 & 0.53 \\
M14 & 0.21 & 0.46 \\
Açıklanan Varyans (\%) & 47.68 \\
\hline
\end{tabular}

Son durumda ölçek tek faktörden ve 16 maddeden oluşmaktadır. Tek faktörün açıkladığı toplam varyans oranı \% $47.68^{\prime}$ dir.

\section{Doğrulayıcı Faktör Analizine (DFA) iliş̧kin Bulgular}

Doğrulayıcı faktör analizinin amacı önceden belli olan bir yapının ele alınan verilerle ne derece doğrulandığını incelemektir (Büyüköztürk, Akgün, Kahveci ve Demirel, 2009). Fen Eğitimine Yönelik Öz Yeterlik Ölçeği'nin açımlayıcı faktör analizinden elde edilen tek faktörlü yapı analiz edilmiş ve yapının uygunluğu modifikasyon indeksi sonuçlarına ve uyum istatistiklerine göre incelenmiştir. OFEYÖÖ’nün doğrulayıcı faktör analizi ile hesaplanan uyum indeksleri 
şöyledir: $x 2$ değeri $=337.26(\mathrm{sd}=104 \mathrm{p}<0,000),(x 2 / s d)=3.24$, RMSEA (Yaklaşık hataların ortalama kare kökü) = .08, $\mathrm{CFI}=.90, \mathrm{NFI}=.96, \mathrm{NNFI}=.97, \mathrm{GFI}=.88, \mathrm{RMR}=0.039$. Doğrulayıcı faktör analizi sonuçlarına göre modelin oldukça iyi olduğu görülmektedir. GFI, CFI ve NFI değerlerinin 0.90 'a yaklaşmasının mükemmel uyumu gösterdiği bilinmektedir (Hair, Anderson, Tatham ve Black, 1998). Bu bulgular ışı̆̆ında tek faktörlü modelin verilerle uyumlu olduğu söylenebilir. Madde-örtük değişken ve örtük değişkenler arasındaki standardize edilmiş katsayıları gösteren yol şeması Şekil 1 'de sunulmuştur.

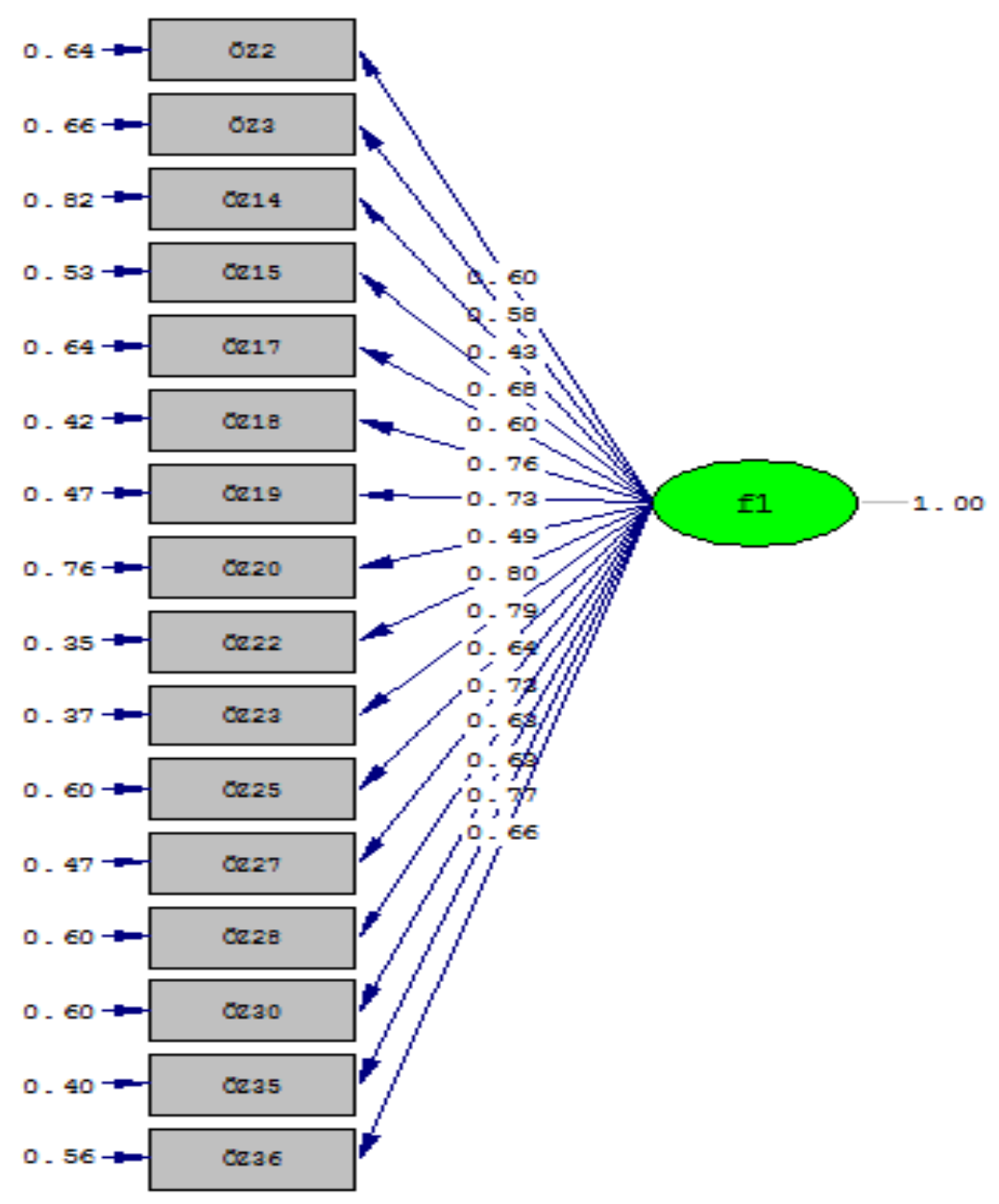

Şekil 1.OFEYöö’ye ilişkin madde-örtük değişken ve örtük değişken arasındaki standardize edilmiş katsayıları gösteren yol şeması

\section{Güvenilirliğe îlişkin Bulgular}

OFEYÖÖ'nün tek faktör altında toplanan maddelerinin iç tutarlılı̆ını tespit etmek amacıyla Cronbach alpha güvenilirlik katsayısı hesaplanmıştır. Buna göre katsayı değeri .92 olarak hesaplanmıştır. Psikolojik testler için .70'lik bir güvenilirlik katsayısının yeterli olduğu göz önüne alındığında (Büyüköztürk, 2008) tespit edilen iç tutarlılık katsayısının oldukça yüksek olduğu söylenebilir. Bu bulgu ölçeğin yüksek düzeyde güvenilir olduğunu göstermektedir.

\section{Maddelerin Ayırt Edicilik Özelliğine Ilişkin Bulgular}

OFEYÖÖ’nün DFA ile belirlenen boyutlarının güvenirliliklerini ve ölçekte bulanan her bir maddenin, kişileri ayırt etmede ölçtükleri özellik açısından ne kadar yeterli olduğunu belirlemek amacıyla madde-toplam korelâsyonları hesaplanmıştır. Daha sonra, ilişkisiz örneklemler için t-testi ile, elde edilen ortalama puanlara göre belirlenen üst \% 27 ve alt \% 27'lik grupların madde puanları arasındaki farkın anlamlıı̆ını tespit edilmiştir.. Sonuçlar Tablo 2 'de gösterilmiştir. 
Tablo 2. OFEYÖÖ’nün faktörlerinin düzeltilmiş madde toplam korelâsyonları ve üst \% 27 ve alt \% 27 grupların puanları arasındaki farka ilişkin ilişkisiz örneklemler için t-testi sonuçları

\begin{tabular}{lll}
\hline Madde No & Madde-toplam Korelâsyonu & $\begin{array}{l}\text { Maddeler için t değerleri } \\
\text { (Üst \%27-Alt \%27) }\end{array}$ \\
\hline M22 & .75 & $16.84^{*}$ \\
M23 & .74 & $19.54^{*}$ \\
M35 & .74 & $18.43^{*}$ \\
M18 & .74 & $18.53^{*}$ \\
M19 & .70 & $18.10^{*}$ \\
M27 & .69 & $15.19^{*}$ \\
M15 & .66 & $18.29^{*}$ \\
M36 & .62 & $13.53^{*}$ \\
M30 & .62 & $13.35^{*}$ \\
M25 & .62 & $13.94^{*}$ \\
M28 & .60 & $13.30^{*}$ \\
M2 & .59 & $13.02^{*}$ \\
M17 & .57 & $11.10^{*}$ \\
M3 & .56 & $11.62^{*}$ \\
M20 & .48 & $9.54^{*}$ \\
M14 & .41 & $9.74^{*}$ \\
\hline \multirow{2}{*}{ 1001 } & &
\end{tabular}

Tablo 2'ye göre, OFEYÖÖ’nün madde-toplam korelâsyonları, .41 ile .75 arasında değişmektedir. Yapılan ilişkisiz örneklemler için t- testi sonuçlarına göre , üst \% 27 ve alt \% 27'lik grupların madde ortalama puanlarında görülen farkların tüm maddeler için anlamlı olduğu belirlenmiştir. Bu bulgu, ölçekteki tüm maddelerin ayırt edicilik kriterini karşıladığını göstermektedir.

\section{Sonuç ve Öneriler}

Okul öncesi öğretmen adaylarının fen eğitimine yönelik öz yeterliklerini belirlemek amacıyla geliştirilen OFEYÖÖ Likert tipindedir ve beşli derecelendirmeye sahiptir. Ölçeğin son hali16 maddeden oluşmaktadır. Ölçek, "Her Zaman (5)”, “Genellikle (4)”, "Sık Sık (3)”, “Nadiren (2)”, "Hiçbir zaman (1)” seçeneklerinden oluşmaktadır .Ölçekten alınacak en düşük puan 16, en yüksek puan ise 80 'dir. Ölçekten alınacak yüksek puan, öğretmen adaylarının fen eğitimine yönelik öz yeterliklerinin yüksek olduğunu göstermektedir. Ölçeğin güvenirliği için hesaplanan Cronbach Alpha iç tutarlılık katsayısı .92dir.Geliştirilen ölçek, okul öncesi öğretmen adaylarının fen eğitimine yönelik öz yeterliklerini ölçmek için yeterli geçerlilik ve güvenilirlik koşullarına sahiptir.Ölçekten alınan puanların yüksekliği arttıkça kişilerin fen eğitimi yapmaya yönelik öz-yeterliklerinin yüksek olduğunu anlamına gelmektedir. Ölçeğin cevaplanması ortalama 10 dakika sürmektedir.

Öğretmenlerin ve öğretmen adaylarının, fen ve matematik vb. gibi belirli bir alana özgü öz yeterlik inançlarına ait ölçümler, onların davranışlarının daha doğru olarak anlaşılmasına imkân tanımaktadır (Üredi ve Üredi, 2006). Bu bağlamda okul öncesi öğretmen adaylarının fen öğretime yönelik öz yeterlikleri ile ilgili olarak alan yazında pek çok çalışma (Alabay, 2006; Ekinci-Vural ve Hamurcu, 2008; Kahyaoğlu ve Yangın, 2007; Olgan, Güner-Alpaslan ve Öztekin, 2014; Okur-Akçay, 2015) yapılmıştır. Ancak bu araştırmalarda kullanılan veri toplama aracına bakıldığında genelde Enochs ve Riggs (1990)tarafından geliştirilen ve Bıkmaz (2004) tarafından Türkçeye uyarlanan "Sınıf Öğretmeni Adaylarının Fen Öğretiminde Öz-yeterlik İnancı Ölçeği” yada genel olarak "Öğretmen adayı öz-yeterlik ölçeği"'nin kullanıldığı görülmüştür. Ancak okul öncesi dönem fen eğitimin kendine özgü yönleri dikkate alındığında doğrudan okul öncesi dönem fen eğitimine yönelik bir öz yeterlik ölçeğine ihtiyaç duyulduğu açıktır. Bu çalışmada geliştirilen ölçek aracılığıyla alan yazındaki bu eksikliğe katkıda bulunulduğu düşünülmektedir.

Bu araştırmada geliştirilen OFEYÖÖ'nün okul öncesi öğretmen adaylarının öz yeterliklerinin inceleneceği araştırmalarda rahatlıkla kullanılabileceği söylenebilir. Diğer taraftan bu ölçek kullanılarak elde edilen veriler okul öncesi öğretmen adaylarının fen eğitimine yönelik öz yeterlikleri ile ilgili yürütülecek karma desenli araştırmalarda da veri çeşitliliği sağlayabilir. Ayrıca bu ölçekte yer alan maddeler üzerinde yapılacak küçük düzeltmelerle birlikte okul öncesi öğretmenleri örnekleminde de geçerlik güvenilirlik çalışmaları yürütülerek ölçeğin okul öncesi öğretmenleri örnekleminde de kullanılabileceği önerilmektedir. Öz yeterliğin öğretmen adaylarının ve öğretmenlerin başarılı 
olmalarını sağlayacak faktörlerden birisi olması nedeniyle öz yeterliğe ilişkin yapılan çalışma sayısının artırılması önerilmektedir.

\section{Kaynakça}

Alabay, E. (2006). İlköğretim okul öncesi öğretmen adaylarının fen ile ilgili öz yeterlik inanç düzeylerinin incelenmesi. Yedi Tepe Üniversitesi Eğitim Fakültesi Dergisi, 2(1), 30-40.

Alisinanoğlu, F., Özbey, S. ve Kahveci, G. (2011). Okul öncesinde fen eğitimi. Ankara: Nobel Yayınları.

Bandura, A. (1977). Self-efficacy: Toward a unifying theory of behavioral change. Psychological Review, 84(2), 191215.

Bıkmaz, H. F. (2004). Sınıf öğretmenlerinin fen öğretiminde öz yeterlilik inancı ölçeğinin geçerlik ve güvenirlik çalışması. Milli Eğitim Dergisi, 161.

Briscoe, C. and Stout, D. (2001). Prospective elementary teachers' use of mathematical reasoning in solving a lever mechanics problem. School Science and Mathematics, 101, 228-235.

Büyüköztürk, Ş., Çakmak Kılıç, E., Akgün, Ö.E., Karadeniz, Ş. ve Demirel, F. (2009). Bilimsel araştırma yöntemleri. Ankara:Pegem A Yayıncılık.

Büyüköztürk, Ş. (2008). Sosyal bilimler için veri analizi el kitabı: istatistik, araştırma deseni spss uygulamaları ve yorum. Ankara: Pegem A Yayıncılık.

Chan, D.W. (2003). Multiple intelligences and perceived self-efficacy among Chinese

Enochs, L. G., and Riggs, I. M. (1990). Further development of an elementary science teaching efficacy belief instrument: a pre-service elementary scale. School Science and Mathematics, 90, 694-706.

Güler, D. ve Bıkmaz. F. (2002). Anasınıflarında fen etkinliklerinin gerçekleştirilmesine ilişkin öğretmen görüşleri. Ankara Üniversitesi Eğitim Bilimleri Fakültesi Dergisi, 1 (2). 249-267.

Gürdal, A., Çağlar, A., Şahin, F., Okçun, F. ve Macaroğlu, E. (1993). Okul öncesi dönemle ilgili fen faaliyetlerine örnekler. 9. Ya-Pa Okulöncesi Eğitimi ve Yaygınlaştırılması Semineri Ankara, Seminer Kitabı, İstanbul: Ya-Pa Yayınları.

Kahyaoglu, M. and Yangin, S. (2007). Views of prospective teachers in elementary teaching departments about professional self-efficacy. Kastamonu Education Journal, 15(1), 73-84.

Karasar, N. (2011). Bilimsel araştırma yöntemi. Ankara: Nobel Yayın Dağıtım.

Kesicioğlu, O.S. ve Alisinanoğlu, F. (2009). Ebeveynlerin okul öncesi dönemdeki çocuklarına (60-72 ay) yaşattıkları doğal çevre deneyimlerinin incelenmesi. Elektronik Sosyal Bilimler Dergisi, 8(29), 1-14.

Kotaman, H. (2008). Öz yeterlilik inancı ve öğrenme performansının geliştirilmesine ilişkin yazın taraması. Uludağ Üniversitesi Eğitim Fakültesi Dergisi, XXI, (I), 111-133.

Küçükyılmaz, E.A. ve Duban, N. (2006). Sınıf öğretmeni adaylarının fen öğretimi öz yeterlik inançlarının artırılabilmesi için alınacak önlemlere ilişkin görüşleri. Yüzüncü Yıl Üniversitesi, Eğitim Fakültesi Dergisi, 2 (2), 1-23.

Milli Eğitim Bakanlığı (2012). Okul öncesi öğretmeni özel alan yeterlilikleri. Web: http://otmg.meb.gov.tr/belgeler/ogretmen_yeterlikleri_kitabi/\%C3\%96\%C4\%9Fretmen_Yeterlikleri_Kitab\%C 4\%B1_okul_\%C3\%B6ncesi_\%C3\%B6\%C4\%9Fretmeni_\%C3\%B6zel_alan_yeterlikleri_ilk\%C3\%B6\%C4\%9Fretim _par\%C3\%A7a_8.pdf adresinden 10 Ocak 2013 de alınmıştır.

Nespor, J. (1987). The role of beliefs in the practice of teaching. Journal of Curriculum Studies, 19(4), 317-328.

Okur-Akçay, N. (2015). Okul öncesi öğretmen adaylarının fen öğretimi öz yeterlik inançlarının çeşitli değişkenlere göre incelenmesi. Route Educational and Social Science Journal, 2(4), 255-262.

Olgan, R., Güner-Alpaslan, Z. \& Öztekin, C. (2014). Okul öncesi öğretmen adaylarının fen öğretimine yönelik sonuç beklentisi inançlarını etkileyen faktörler. Eğitim ve Bilim.39(173). 288-300 
Öncü, H.(2012). Akademik öz-yeterlik ölçeğinin Türkçeye uyarlanması. Ahi Evran Üniversitesi Kırşehir Eğitim Fakültesi Dergisi (KEFAD), 13(1),183-206.,

Özdemir, M.S.(2008).Sınıf öğretmeni adaylarının öğretim sürecine ilişkin öz-yeterlik inançlarının çeşitli değişkenler açısından incelenmesi. Kuram ve Uygulamada Eğitim Yönetimi, 54, 277-306.

Teti ,D. and Gelfand, D.(1991). Behavioral competence among mothers of infants' in the first year: the meditational role of maternal self-efficacy. Child Development, 62(5), 918-929.

Üredi, I ve Üredi, L. (2006). Sınıf öğretmeni adaylarının cinsiyetlerine, bulundukları sınıflara ve başarı düzeylerine göre fen öğretimine ilişkin öz-yeterlik inançlarının karşılaştırılması. Web:http://oldweb.yeditepe.edu.tr/Yeditepe adresinden 25 Ocak 2013 tarihinde alınmıştır.

Vural, D. E. and Hamurcu, H. (2008). Preschool teacher candidates' self-efficacy beliefs regarding science teaching lesson and opinions about science. Elementary Education Online, 7(2), 456-467.

Yıldııım, F. ve İlhan, Ö.i. (2010). Genel özyeterlik ölçeği Türkçe formunun geçerlilik ve güvenilirlik çalışması Türk Psikiyatri Dergisi, 21(4), 301-308. 